\title{
Analysis by Finite Element Method to Redesign a Jointed-Telescopic Crane for Elevation of Personnel
}

\author{
J. A. Diosdado-De la Peña, ${ }^{1}$ A. J. Balvantín, P. A. Limón-Leyva, and P. A. Pérez-Olivas \\ Department of Mechanical Engineering, University of Guanajuato, Salamanca, Guanajuato, Mexico \\ 1 jose.diosdado@ugto.mx
}

УДК 539.4

\section{Скінченноелементний аналіз перепроектування зчленовано-телескопічного підйомного крана для підняття персоналу}

\author{
Х. А. Діосдадо-Де ла Пена, А. Х. Балвантін, П. А. Лімон-Лейва, П. А. Перес-Олівас \\ Факультет машинобудування, Університет Гуанахуато, Саламанка, Гуанахуато, Мексика
}

\begin{abstract}
Наведено чисельний розрахунок підйомного крана для підняття персоналу на основі скінченноелементного аналізу, підтверджений експериментальними даними по складових його компонентах. Оригінальна модель підйомного крана включає зчленовані секиії компланарних стріл $i$ телескопічної секиії колінеарних стріл. Максимальні навантаження та іх вплив на складові компоненти підйомного крана визначено згідно зі стандартом ANSI/SIA 92.9, щуо використовується для моделей підйомного крана, розповсюджених і комериіалізованих у Мексииі. Скінченноелементний аналіз базується на методі складання кінематичних пар з урахуванням динамічного навантаження та їх результуючої реакції на кожен елемент. Механічні характеристики кожного компонента оцінюються за параметром мінімального фактора безпеки. Однак у тих компонентах, де ией фактор не відповідає стандарту, пропонується безліч модифікацій для перепроектування даного компонента. Проведено детальний структурний аналіз запропонованої їх модернізації й отримано більш високі фактори безпеки порівняно $з$ оригінальною моделлю. Чисельні результати запропонованої модернізації підтверджено експериментальними вимірюваннями деформацій при використанні тензодатчиків, установлених на прототипі підйомного крана, який виготовлено згідно із запропонованою перепроектованою моделлю.
\end{abstract}

Ключові слова: підйомний кран для підняття персоналу, скінченноелементний аналіз, конструктивне перепроектування, метод складання кінематичних пар, аналіз із урахуванням динамічного навантаження.

Introduction. Commonly, the design of cranes is carried out in accordance with the manufacturer's experience or applying reverse engineering on existing designs [1,2]. These development processes result in frequent repairs to the constituent components of the crane, without any numerical validation of their mechanical performance to any standard $[3,4]$. In order to avoid such inconveniences, a variety of support technologies and analysis methods have been used on the design of this kind of machinery.

Among the methods commonly used for the analysis of the constituent mechanisms of a crane, the synthesis of kinematics and its solution through numerical methods [5-9] and the analytic models for optimization [10,11] are highlighted. Nevertheless, the most frequently used technologies include computer-aided design and engineering software (CAD and CAE), which are used for modeling a given three-dimensional geometry $[12,13]$ and its subsequent simulation under different working conditions [14]. Some of these 
programs use the finite element method (FEM) to synthesize the constituent components and to assess their behavior under a variety of applied loads [15].

Using commercial finite element analysis software, different kinds of cranes have been studied with different features such as workshop cranes $[13,16]$, tower cranes $[1,9$, 17-20], marine platform cranes [5, 21], caterpillar cranes [14, 15], telescopic cranes $[6,7$, $22,23]$, bridge cranes [10-12, 24-26] and jointed cranes [8]. In most of these studies, structural static analysis has been carried out to determine the performance of the crane under live and dead loads $[1,10,12,14,16,18,21-23,25]$. In addition, some studies include inertial effects through a dynamic load factor in a static analysis [21] or with an analysis of explicit dynamic loads [18, 22]. Han et al. [21] combined finite element and finite volume methods in order to add the effect of wind on a structure of a marine platform crane. Other authors aimed their studies towards the behavior of the structure under cyclic loads such as mechanical vibrations, so that modal and harmonic analysis have been necessary $[17,20,24,26]$. The validation of a finite element analysis is commonly made by comparing analytic data, based on solid mechanics, and experimental data measured by strain gauges [18, 23-25]. The analysis of static loads might result in numerical data with error factors less than $5 \%$ in comparison to the experimental data [23]. However, a model with dynamic loads is more reliable to simulate a failure, even when its correlation with experimental data has a greater deviation [22].

Traditionally, the experimental measurements of stresses are carried out through measurements of strains from the structure when is loaded [24, 27]. However, there are some components whose strains cannot be easily obtained, given the risks of measuring for the equipment or the personnel responsible for performing the analysis. For this reason, recently technologies such as strain gauges have been widely used, given the need for measuring strains in remote or risky working areas [27-30]. Moreover, other technologies have been useful in combination with strain gauges, such as data transmission through Wi-Fi [31-33]. However, a common issue with this kind of data transmission is that it might be interfered with by other transmission channels. Also, factors such as electric and combustion engines, vibrations of the mechanical system, etc., might induce noise to the signal transmitted. Recently, diverse techniques for signal conditioning have been reported in the literature [34]. Additionally, devices such as the Wheatstone bridge have a set of amplifiers and filters to attenuate and improve the transmitted signal from the strain gauges $[34,35]$.

In this paper the constituent components of a crane, designed with two traditional configurations, are analyzed. The design of the crane consists of a jointed section with coplanar arms and a telescopic section with collinear arms. This crane design reaches a maximum height of $13 \mathrm{~m}$ and it is intended to be carried by a motor vehicle. For the numerical analysis, the original design of the constituent components of the crane were designed from the experience of the manufacturer (company with location and distribution in Mexico), and validated under the standard ANSI/SIA 92.2 for aero devices of elevation and rotation assembled on vehicles [4]. This assessment was made considering loads recommended by the standard and their effects on the components during the elevation of the personnel from the initial position to the desirable working position. In this structural analysis, different working positions and dynamic loads on the constituent components were considered. The referential parameter of mechanical performance of each component is the minimum security factor (MSF). On the basis of results from the analysis, some modifications, or even a total redesign, are proposed, on those components with insufficient MSF value in order to meet the standard. Finally, the numerical analysis of the proposed redesign was validated with experimental data from strain gauges attached to a 1:1 scale prototype of the crane. A detailed description of materials and methodology used in this work is given in the following Section. 


\section{Materials and Methodology.}

1.1. Materials. In the modeling of the constituent components of the crane, standard materials suitable for the construction of this kind of mechanisms were considered. For the numerical analysis of such components by finite element, mechanical properties, such as the Young modulus $(E)$, yield strength $\left(S_{y}\right)$, Poisson's ratio $(v)$, and density $(\rho)$ of materials, are required. Such mechanical properties were mainly provided by the supplier (Serviacero [36]) and found in literature in the web (MatWeb [37]) as can be observed in Table 1. Note that the properties values of $E, v$, and $\rho(E=200 \mathrm{GPa}, v=0,26$, and $\rho=7850 \mathrm{~kg} / \mathrm{m}^{3}$ ), were similarly considered for the different kinds of steels.

$\mathrm{T}$ a b 1 e 1

Properties of Steels Used in the Crane

\begin{tabular}{|c|c|}
\hline Material & Yield strength (MPa) \\
\hline A36 & 250 \\
\hline A500 Gr A & 228 \\
\hline A500 Gr B & 290 \\
\hline AISI 1018 & 370 \\
\hline A53 Gr B & 241 \\
\hline API 5L x42 L290 & 290 \\
\hline
\end{tabular}

1.2. Methodology. The methodology used in this work, involved the modeling of the original crane, which was designed in commercial CAD software. Subsequently, after an initial structural analysis was performed by finite element models, main parameters were established to assess the mechanical performance of each constituent component at a certain working position, previously determined. The distribution of the loads and reactions along the components are also shown, when modeled by finite element.

1.2.1. Referential Standard. The establishment of loads and the mechanical performance criteria were in accordance with the standard AISI/SIA 92.2-2009 [4]. This standard states the maximum strength for designing a crane, which should be a function of the structural load capacity and its own weight. In addition, the design strength should not exceed $50 \%$ of the yield strength in ductile materials and $20 \%$ of the ultimate strength in fragile materials, stipulations also written as security factors 5 and 2, respectively. The standard also indicates to take into account stress concentrations, dynamic loads, loads due to working operation at a slope of $5^{\circ}$, room temperature, loads due to transportation and movements, wind effects on the structure, loads due to manual operation ( $25 \mathrm{~kg}$ per operator) and column loads.

1.2.2. CAD Modeling. The original design of the crane was provided by the manufacturer and it was synthetized in a CAD software program named CATIA V5®. The original design of the crane along with a list of the main constituent components of the crane to be studied can be observed in Fig. 1. Nevertheless, this work discards the analysis of commercial components.

Once the CAD crane model was ready, some critical positions were proposed in accordance with the standard and the maximum strength that the structure might show at these critical positions. Figure 2 shows the position parameters, where $\alpha$ is the inclination angle of the telescopic arm, which runs from 0 to $80^{\circ}, \beta$ is the inclination angle of the parallel arms, which runs from 0 to $87^{\circ}$, and $\delta$ is the linear displacement of the inner arm that runs from 0 to $2,868 \mathrm{~mm}$. According to these parameters, seven critical positions were established, which represent working positions and some transitions of the whole mechanism 


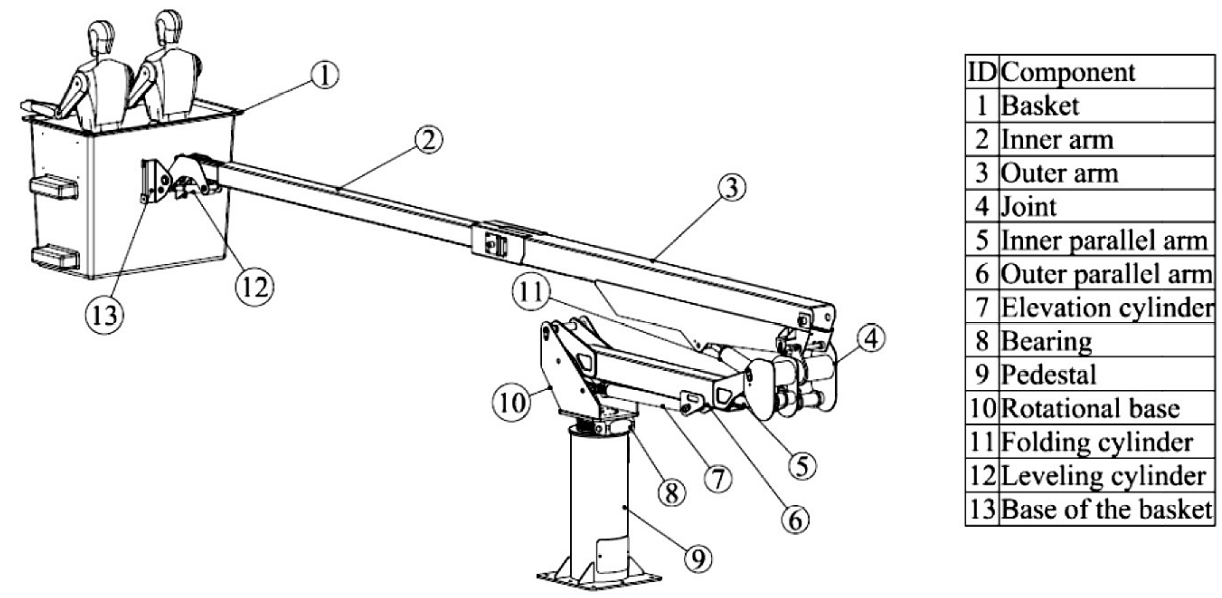

Fig. 1. Original model of the crane and its constituent components.

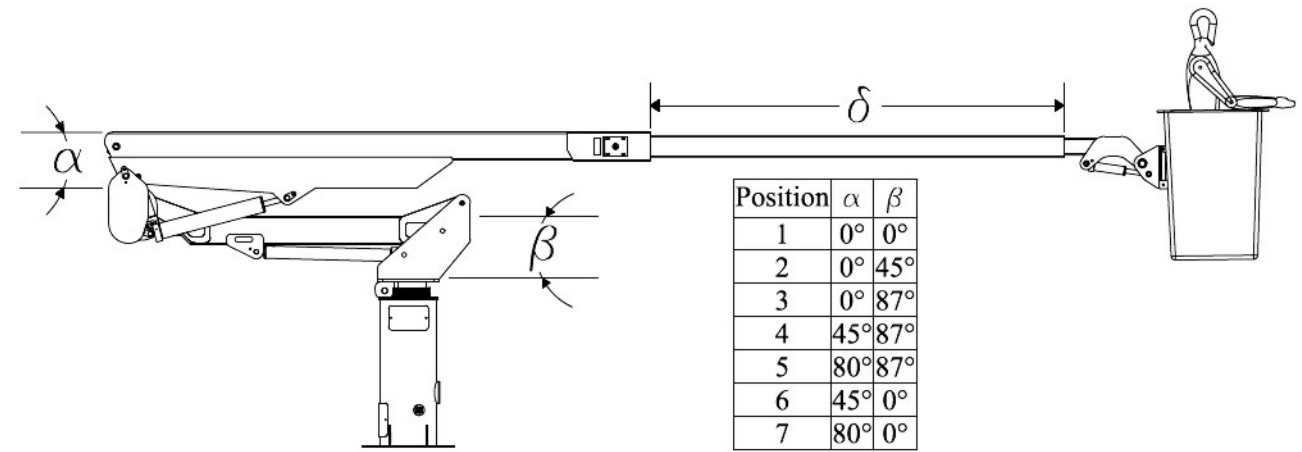

Fig. 2. Parameters of position, $\alpha, \beta$, and $\delta$, and its configurations of analysis.

between one given point to another. Every position, therefore, was considered with the parallel arms fully extended, given that this condition results in maximum momentum at the base of the crane.

1.2.3. Establishment of Dynamic Loads. With the purpose of determining dynamic loads, the original model of the crane was imported to the CAD module of the structural analysis software ANSYS $15 \AA$. During this process every constituent component was changed into surfaces with their respective thickness of profiles and plates while maintaining the geometrical shapes. Subsequently, the structural analysis of the components took place.

The first stage consists of a structural analysis of the support base of the crane, where the weight of two operators (1079 $\mathrm{N}$ each) and the weight of the basket carrying working tools $(981 \mathrm{~N})$ were considered. Note that such weights were applied on the mass centre of the operators and objects. In addition, a horizontal load is added at the top of the basket $(444.8 \mathrm{~N})$ which represents loads due to working manoeuvres by the operators, as shown in Fig. 3.

In the dynamic analysis, the reaction loads at the base of the basket determine the load applied at the top of the crane, as shown in Fig. 4. The aim of the dynamic analysis is to know the reaction loads at the joints of the constituent components and their effects due to the elevation process. The only constraints for these parameters are the structural load capacity and its own weight. Moreover, these reactions represent flexion and column loads on the components. Hence, it is established that the piston rod from the elevation cylinder is totally extended in around $13 \mathrm{~s}$, whereas the piston rod from the folding cylinder is 

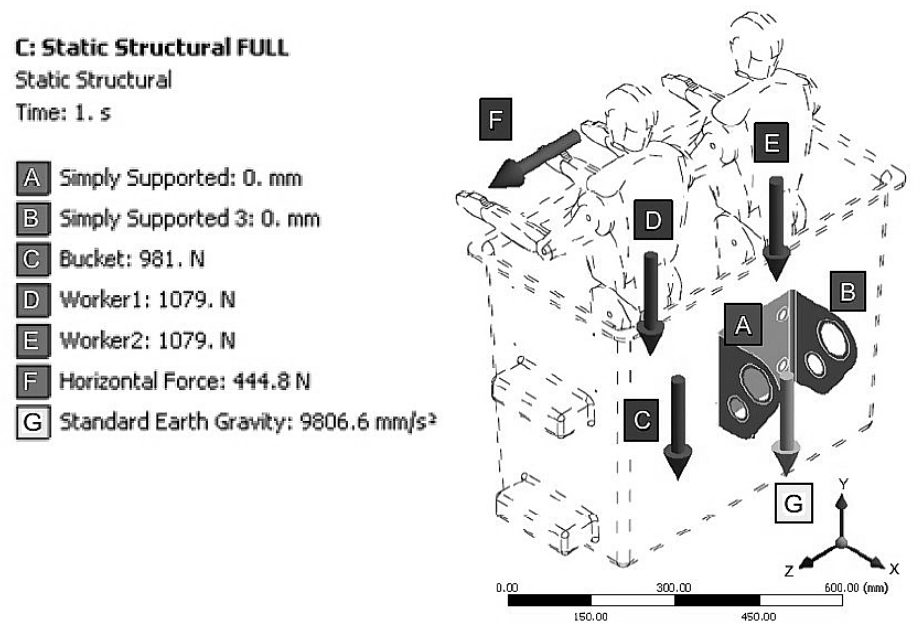

Fig. 3. Loads at the base of the basket in the finite element model: simple supports $(A$ and $B)$, weight of the basket with tools $(C)$, weight of the operators ( $D$ and $E$ ), load due to working manoeuvers $(F)$, and effect of gravity $(G)$.

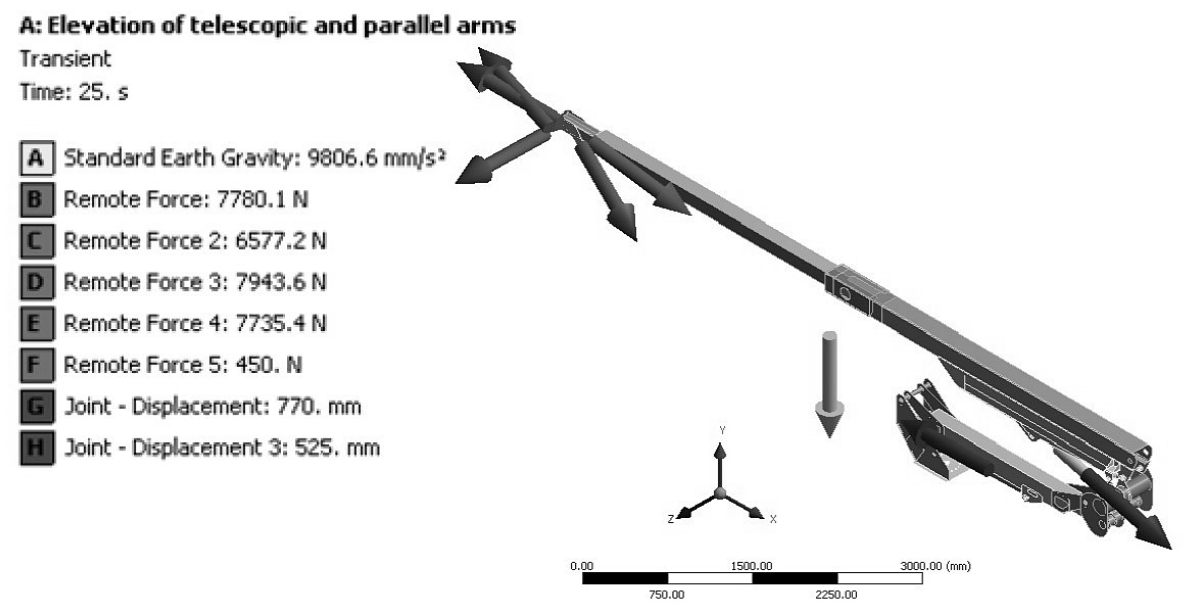

Fig. 4. Loads used in the dynamic analysis of the crane. $(A)$ weight, $(B-F)$ loads transferred from the base to the basket, and $(G, H)$ displacements in the folded cylinder and in the elevation cylinder.

extended in around $12 \mathrm{~s}$. Hence, the total elevation of the whole crane is estimated to take around $25 \mathrm{~s}$ in accordance with the requirements of the manufacturer. For the structural analysis, the material properties were applied to the respective constituent components, excluding effects due to temperature, wind and working operation at a slope of $5^{\circ}$.

As mentioned previously, the assembly method of kinematic pairs was used during the analysis for obtaining correlations of evolution of loads as passing of time in every joint of the mechanism. Figure 5a shows the reaction momentum on the rotational base at the beginning of the elevation of the mechanism. As shown in Fig. $5 \mathrm{~b}$ and successively in Fig. 5c, this momentum reaction shows a given variation as time increases. Finally, Fig. 5d shows the evolution of the reaction at each time moment previously defined to be studied. Once the relative time-positions are determined, loads and momentums can be assigned to the components modeled by finite element method, as can be observed in the following section, where loads and momentums are revealed for each component for each working position. 


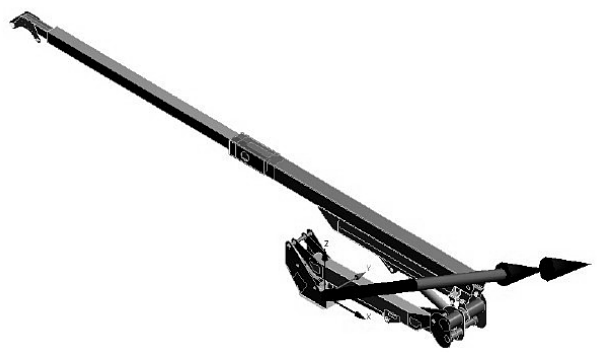

$\mathrm{a}$

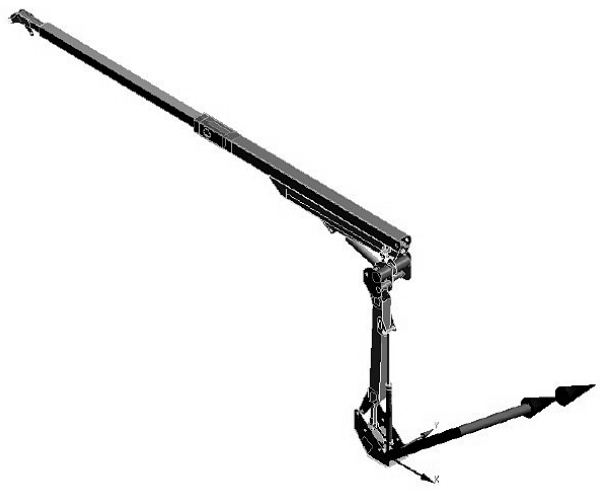

b

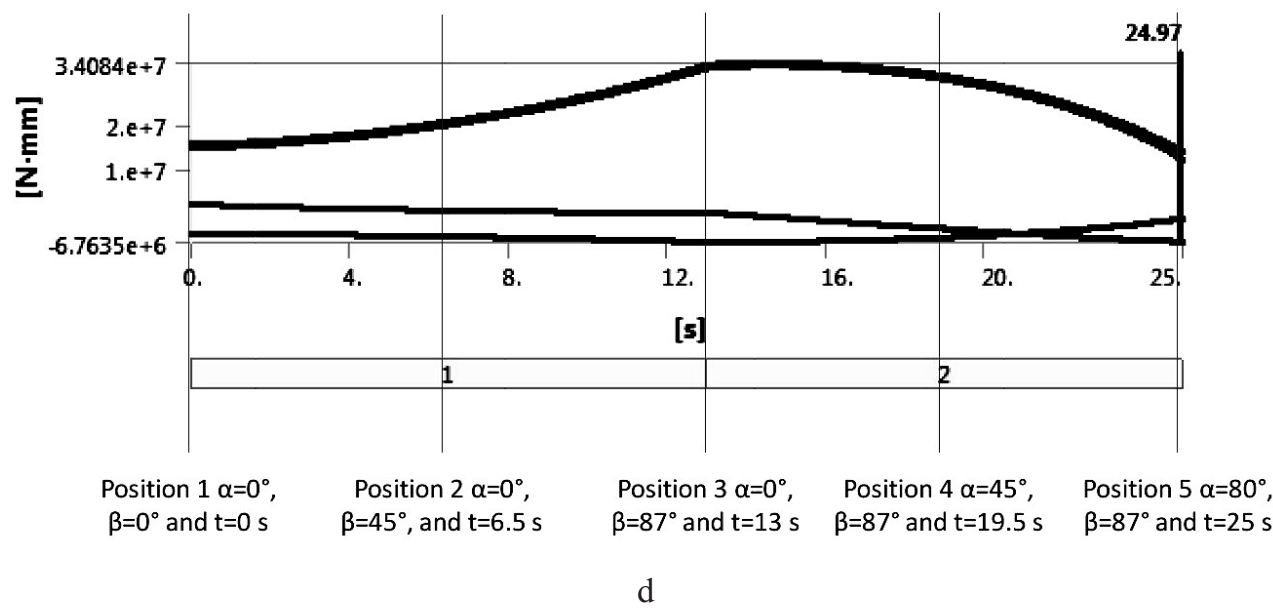

Fig. 5. Reactions on the rotational base: (a) position 1; (b) position 3; (c) position 5; (d) evolution in function of simulation time.

1.2.4. Finite Element Model. As previously mentioned, each constituent component was simulated with a set of surfaces, helpfully synthetized by using shell elements, in the ANSYS $15 \circledR$ software. The inputs in this software included materials, mechanical properties, applied loads and working conditions. For instance, the materials used were considered as elastic isotropic and the applied loads and inclination degrees were parameterized in the software with the purpose of speeding up the outputs from the scenarios described above. Note that, in every scenario, the respective weights were added to the model, such as the support base of the basket observed in Fig. 3, the inner and outer arms, the inner and outer parallel arms, joint, the rotational base and the pedestal, as shown in Figs. 6a and 6g. 


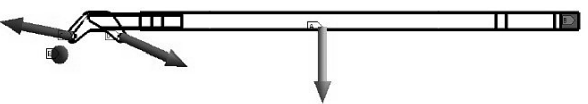

a
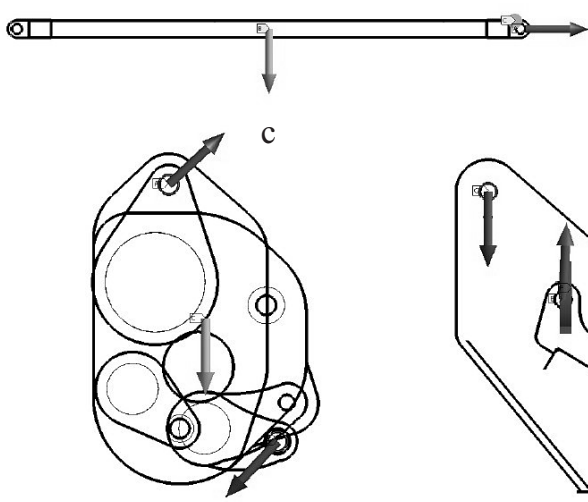

e

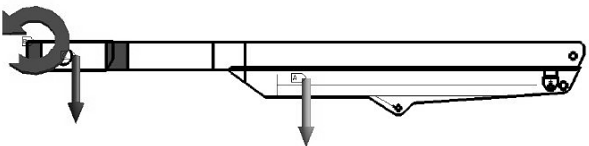

b

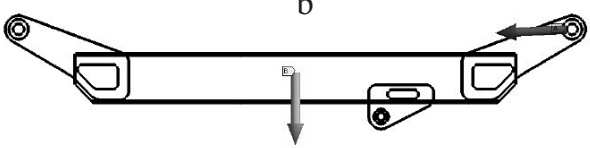

d

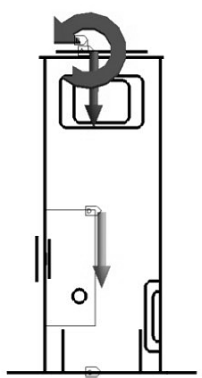

g

Fig. 6. Finite element models with respective loads in: (a) inner arm, (b) outer arm, (c) inner parallel arm, (d) outer parallel arm, (e) joint, (f) rotational base, and (g) pedestal.

Once the structural analysis was carried out for each constituent component under the proposed loads, the data was useful to calculate security factors for the original model which are exposed in the section of results.

2. Results. As mentioned in the last section, the security factors obtained by the distortion energy theory, used by the ANSYS 15® software, are revealed for each constituent component of the crane.

2.1. Original Design. The MSF were obtained for each constituent component according to the defined loads and positions, parameters which defined the critical positions of the crane. Table 2 summarizes the applied loads and the consequent MSF for each component from the original design. These parameters reveal that the constituent components are insufficient to meet the standard. Therefore, a number of structural modifications are proposed to the original design in order to improve the mechanical performance of the whole crane. Such modifications are described in the next section.

$\mathrm{T}$ a b 1 e 2

Summary of MSF and Critical Position of the Original Design

\begin{tabular}{||c|c|c|c||}
\hline Component & Applied load & $\begin{array}{c}\text { Critical } \\
\text { position }\end{array}$ & MSF \\
\hline Base of the basket & Loads described in Section 1.2.3 & $1-7$ & 1.15 \\
\hline Inner arm & Reactions transferred to the base of the basket & 4,6 & 1.57 \\
\hline Outer arm & Load and bending momentum at the end & 4,6 & 1.60 \\
\hline Joint & Reactions at the joints with the outer arm & $1-3$ & 0.89 \\
\hline Inner parallel arm & and the folding cylinder & 3 & 0.90 \\
\hline Outer parallel arm & Pure tension load & 3 & 0.73 \\
\hline Rotational base & Reactions of the parallel arms and elevation cylinder & 3 & 0.05 \\
\hline Pedestal & Load and momentum transferred by the rotational base & 3 & 0.50 \\
\hline
\end{tabular}


2.2. Modifications Proposed. In this section, various strategies for structural modifications were assessed in order to increase the respective MSF values of the constituent components which failed to meet the standard. The first strategy consists in increasing the thickness of the components, the second one in modifying some geometries and finally the total redesign of some components was implemented. The specific strategies for structural modifications and their effect on mechanical performance are described as follows.

In base of the basket, a simple increase of thickness from 4.8 to $6.4 \mathrm{~mm}$ was implemented, and as a result the MSF value increased to until a value of 2.0, which, satisfies the standard as can be seen in Fig. 7.

The inner arm was simply modified by increasing the thickness of the inserted canal from 7.9 to $12.7 \mathrm{~mm}$; as a consequence, the MSF value increased to 2.15 at its critical position, as shown in Fig. 8.

Similarly, the outer arm was modified by increasing the thickness of the reinforcement on the component from 4.8 to $7.9 \mathrm{~mm}$, which satisfies the standard with a MSF value of 2.18, as shown in Fig. 9.

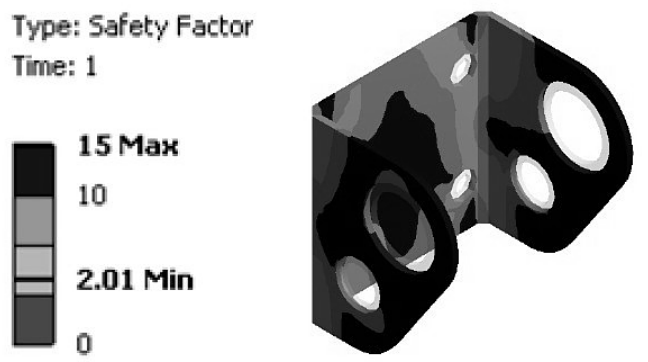

Fig. 7. Security factor in the base of the modified basket, 2.01.
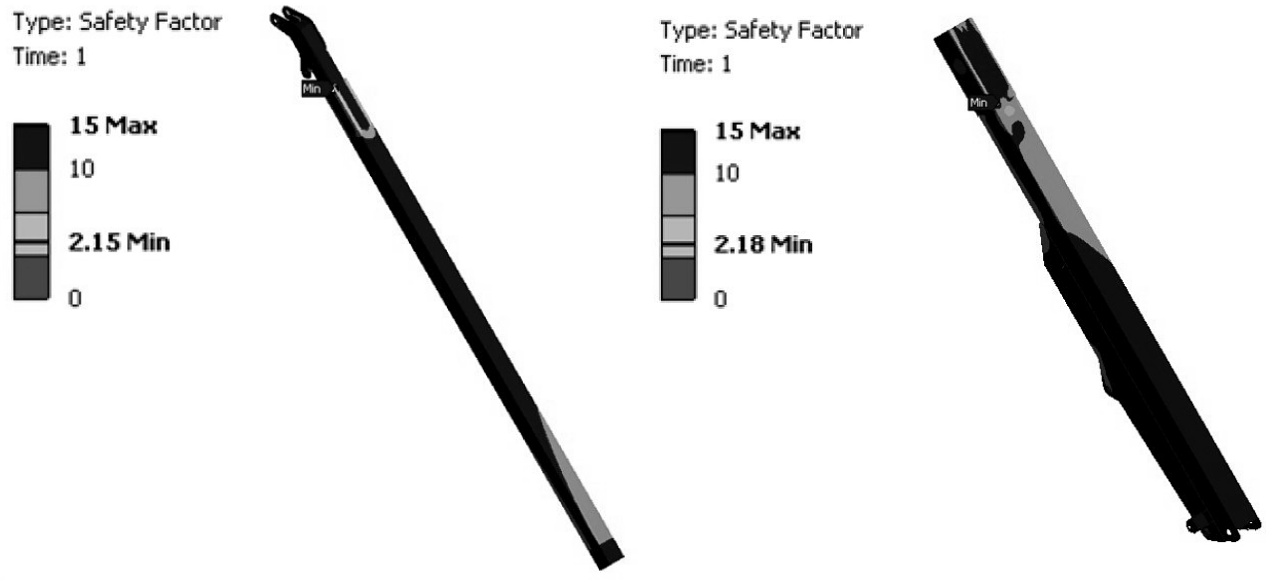

Fig. 8. MSF of the modified inner arm, 2.15. Fig. 9. MSF of the modified outer arm, 2.18.

Nevertheless, the joint was considerably modified, firstly, by changing the thickness of the vertical plates from 7.9 to $9.5 \mathrm{~mm}$, then, by increasing the schedules of the upper and lower tubes that make up the component. Moreover, the geometries of the support bases were modified in order to reduce stress concentrations, and steel flat bars were attached to the back and hole of the central plate. As a result, the security factor increased to a value of 2.02 at a critical position in comparison to the original design. However, these proposed 
modifications changed the critical positions of the original design, positions 4 and 6 becoming the new critical positions of the element with a MSF value of 1.75. Even though this MSF value still remains insufficient according to the standard, these modifications increased the MSF value by approximately $97 \%$ with respect to the original design, which is located in an area with no mobile parts, as shown in Fig. 10.

In the case of the inner parallel arm, the increase in thickness, the change in geometry and adding supporting elements resulted in an insufficient and unacceptable MSF value according to the standard. Thus, a total redesign of the component was proposed with a tube API 5L x42 L290, with a nominal dimeter of $63 \mathrm{~mm}$ as a base. As a consequence, the MSF value of the component increased to a value of 2.21 as shown in Fig. 11.

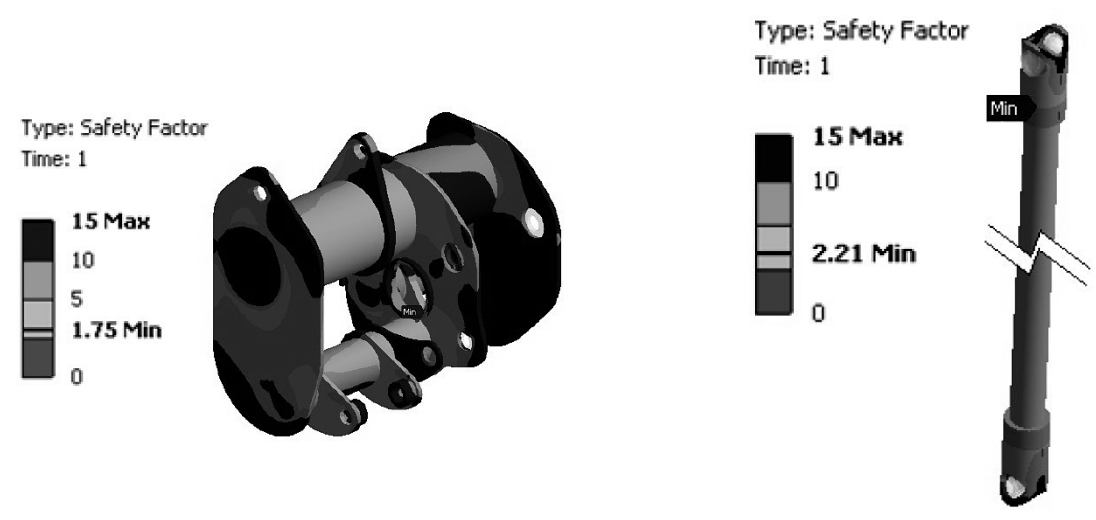

Fig. 10. MSF in the modified joint, 1.75. Fig. 11. MSF in the modified inner parallel arm, 2.21.

The outer parallel arm was modified with diverse changes of thickness and geometry. These modifications consisted of changing the main body of the component with a $25 \%$ higher HSS profile, as well, changing the shape and thickness of the upper, medium and lower supports. As a result, the MSF value increased to a value of 1.80 at the critical position, approximately 1.5 times higher than the original design of the component, as can be seen in Fig. 12.

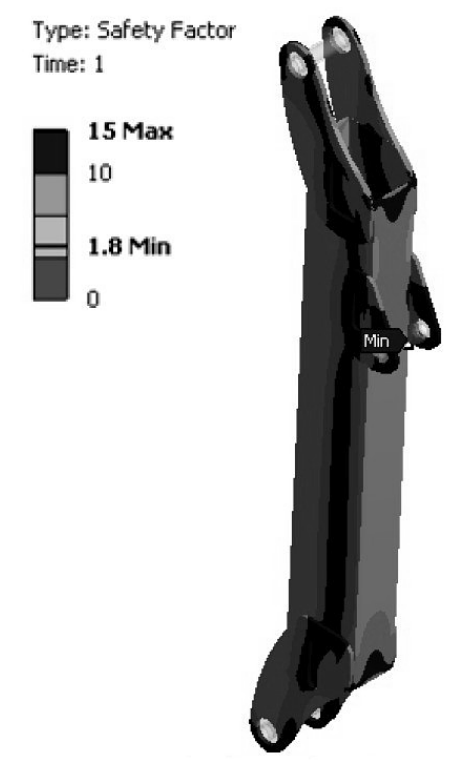

Fig. 12. MSF in the modified outer parallel arm, 1.80 . 
As can be observed in Table 2, the rotational base is the component with lower MSF in the original design of the crane. Hence, this component was seriously modified by changing thickness and geometry; new elements were also included as inner supports in order to increase the MSF to a value of 2.06, as shown in Fig. 13.

Finally, the pedestal was modified by increasing the thickness of the tube from 6.4 to $7.9 \mathrm{~mm}$, inclining the lateral supports to $45^{\circ}$ and increasing their thickness and height to increase the stiffness of the assembly. The thickness of the lower plate and the upper flange were also increased to 28.6 and $50.8 \mathrm{~mm}$, respectively. As a result, the MSF increased to a value of 1.93 , barely $3.5 \%$ below the target as shown in Fig. 14. In the following Section, the experimental system is described with the methodology used for validation of data.

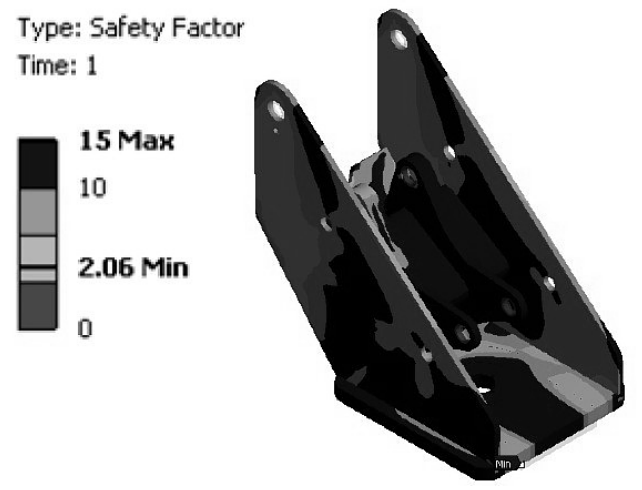

Fig. 13. MSF in the modified rotational base, 2.06.

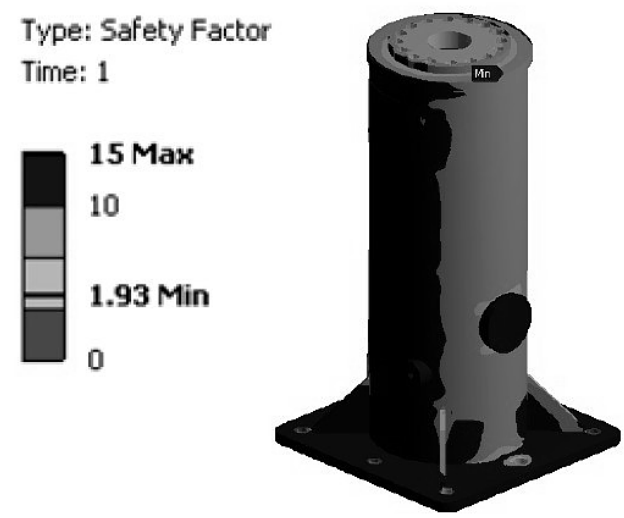

Fig. 14. MSF of the modified pedestal, 1.94.

2.3. Experimental Validation. On the basis of results from the modeling, a new design was proposed which would be suitable for the expected loads that the crane is subjected to. The new design was shown to the manufacturer, who ratified the feasibility of the experimental prototype. Once the mechanism of elevation was built and mounted on a motor vehicle, the experimental validations of the finite element models were carried out. To do this, the use of strain gauges attached to constituent components of the crane was proposed, with the purpose of measuring strains under the known loads. The piezoresistive sensor selected for measuring strains was the rosette CEA-06-250US-350 for general purposes. This sensor has a configuration of four meshes distributed to $90^{\circ}$ with a gauge factor of 2.08 and a range of stress of $+5 \%$, with a sensing area of $2.5 \times 2.0 \mathrm{~cm}$. The mesh configuration allows the induced variations due to electromagnetic noise to be balanced [28]. In addition, the use of a telemetric system for the data transmission was considered.

The configuration of an experimental system for the transmission of the signal from the strain gauges consists of a terminal National Instrument (NI) 9949 that connects the sensor to the module NI 9237 for the conditioning and interpretation of signals, as well as a wireless chassis NI 9191 for data transmission via Wi-Fi. Subsequently, the wireless signal is acquired by a computer, where a virtual instrument (VI) for the acquisition, visualization, processing and storage processes of signals is employed. The VI used was built using LabView 2015® commercial software. The schematic of the experimental system for acquisition, transmission and processing of signals is shown in Fig. 15.

The experiments consisted in positioning the crane prototype in a set of positions of interest, similar to those considered in the numerical analyses, with a known load in the basket (209 kg, concrete blocks) and five iterations. In these positions, strains were measured at central points of three components of the prototypes: pedestal, outer arm and outer parallel arm. These measurements were carried out with the data acquisition system 


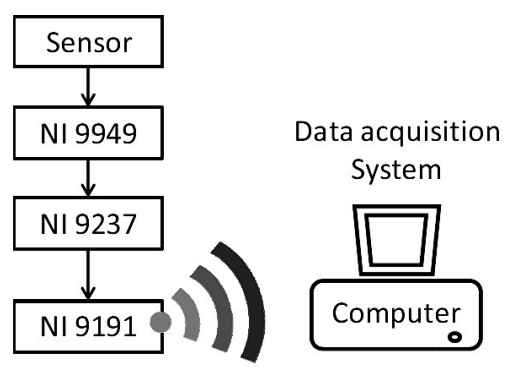

Fig. 15. Experimental system for acquisition, transmission and processing of signals.

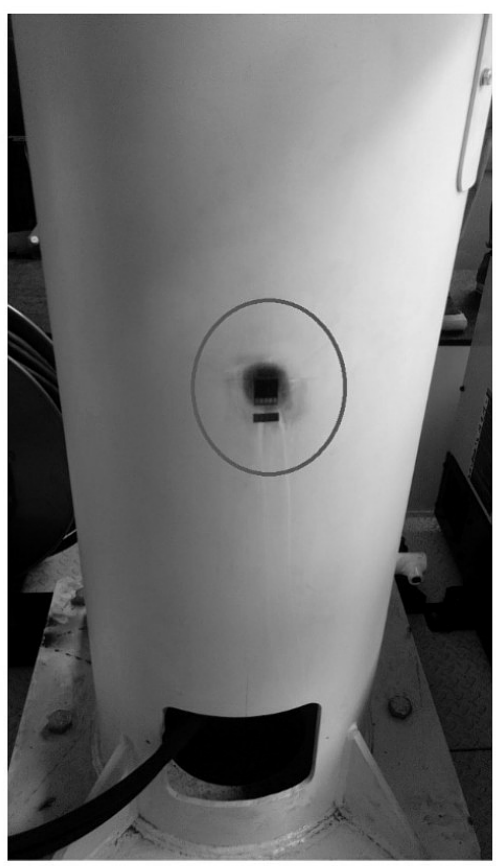

a

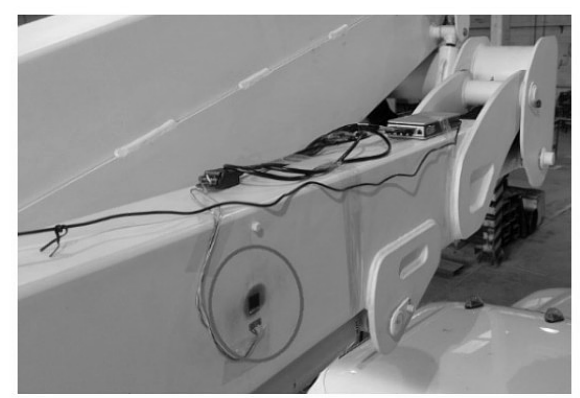

b

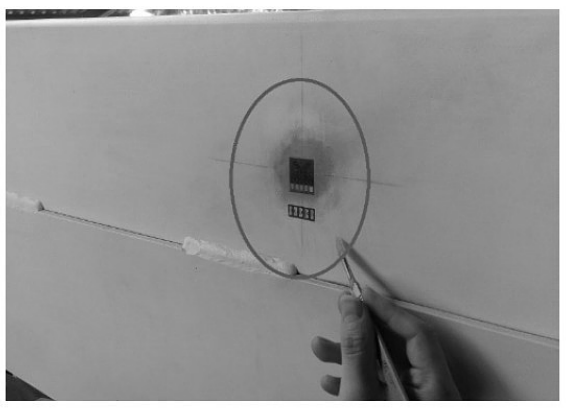

Fig. 16. Strain gauges in: (a) pedestal, (b) outer parallel arm, and (c) outer arm.
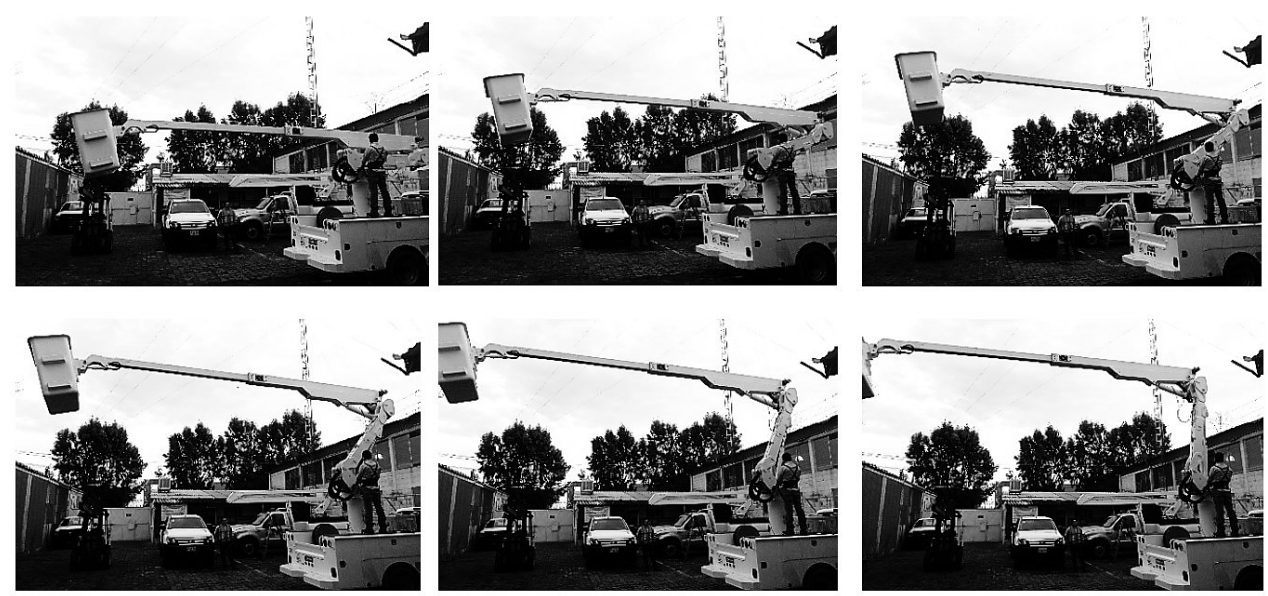

Fig. 17. Movement sequence to position the prototype crane in the working position 3: elevated parallel arms $\left(\beta=87^{\circ}\right)$ and extended and horizontal telescopic arms $(\delta=2800 \mathrm{~mm}, \alpha=0)$. 


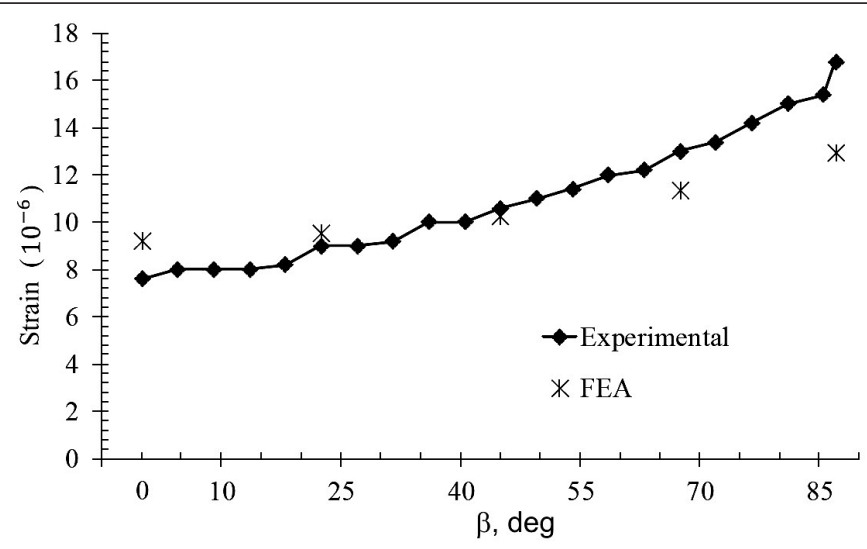

Fig. 18. Comparison of numeric and experimental data of strain values of pedestal.

described previously. Figure 16 shows the strain gauges placed on the components mentioned. Figure 17 shows a movement sequence of the prototype to reach the working position 3, detailed in Fig. 2.

The finite element models were repeated considering only the load of $209 \mathrm{~kg}$ in the basket and strains were obtained from similar central points to the experimental prototype. These numerical results were compared with the averages of experimental data. Figure 18 shows a plot of strain versus position $\beta$ of numerical and experimental data. Comparisons of data from other components showed that they were similar. Thus, it can be established that the finite element models of the proposed crane design are suitable to simulate the mechanical performance of the mechanisms of the cases studied.

Conclusions. This study has analyzed a crane used for elevation of personnel which combines two configurations: jointed and telescopic sections. The original design of the mechanism is based only on the experience of the designer and manufacturer. The numerical analysis involves dynamic and inertial loads applied on different constituent components of the crane.

The loads applied on the crane were obtained from the standard ANSI/SIA A92.2. Such loads were determined per constituent component from the general movement of the in-service crane. The resulting data allows loads at each component to be correlated with previously determined working position.

The analysis of the original jointed-telescopic design of the crane revealed an insufficient mechanical performance with security factors within a range from 0.05 to 1.6 , that are significantly below the value of 2 specified by the standard. Therefore, a number of analyses and consequent different modifications in diverse components were suggested, which MSF values within a threshold from 1.75 to 2.21 to be reached. In those cases, where the MSF values were insufficient to meet the standard, it was observed that the MSF became more than twice the original values in the redesigned model. Thus, it might be considered that the manufacture of the first prototype is functional.

The critical conditions for the components mounted over the joint are those where the inclination angle of the telescopic arms $(\alpha)$ is $45^{\circ}$. Such elements required minor modifications to increase the mechanical performance.

In addition, the components below the joint show their critical positions when the parallel arms are at their maximum inclination $\left(\beta=87^{\circ}\right)$ and the telescopic arms are at the minimum inclination $(\alpha=0)$. At this position, the maximum horizontal position is reached. Hence, the considered loads and the upper components result in the maximum momentum for rollover, it being the lower components that counteract the rollover momentum. Thus, these components are significantly modified. As a consequence of the 
proposed modifications, an improved mechanical performance of the crane was obtained, in comparison to the original design.

Finally, once the proposed modifications were assessed, the project proceeded to the manufacture of a prototype, where functional tests and an experimental study by measuring strains were carried out to validate the finite element models. A comparison of numerical and experimental data shows consistency of strain values; it can be concluded, therefore, that the models used are suitable to simulate the mechanical performance of the jointedtelescopic crane. Hence, in case of future modifications to the mechanism, these can firstly be implemented into the finite element models, in order to subsequently improve the prototype.

On the basis of the results obtained, it can be established that the analysis here presented is essential for designing specialized equipment.

Acknowledgments. The authors want express their gratitude to Dr. Hector Plasencia Mora, Executive Director of Guanajuato Tecno-Park, to Dr. Miguel Torres Cisneros, lecturer of University of Guanajuato, to Mario Villegas Urquidi, CEO of Tecnica Hidraulica del Bajio S.A de C.V and to Council of Science and Technology of Guanajuato (CONCYTEG) for all the support given to this project. A special mention must be given to Leonel Esquivel Villegas, bachelor student of mechanical engineering of the University of Guanajuato for his technical support provided during the experimental tests.

\section{Резюме}

Представлен численный расчет подъемного крана для поднятия персонала на основе конечноэлементного анализа, подтвержденный экспериментальными данными по составным его компонентам. Оригинальная модель подъемного крана состоит из сочлененных секций компланарных стрел и телескопической секции коллинеарных стрел. Максимальные нагрузки и их влияние на составные компоненты подъемного крана определены согласно стандарту ANSI/SIA 92.2, применяемому для моделей подъемного крана, распространенных и коммерциализированных в Мексике. Конечноэлементный анализ основан на методе сборки кинематических пар с учетом динамических нагрузок и их результирующей реакции на каждый элемент. Механические характеристики каждого компонента оценены по параметру минимального фактора безопасности. Однако в тех компонентах, где этот фактор не соответствует стандарту, предложено множество модификаций для перепроектирования данного компонента. Выполнен также подробный структурный анализ предложенной их модернизации и получены более высокие факторы безопасности по сравнению с оригинальной моделью. Численные результаты предложенной модернизации подтверждены экспериментальными измерениями деформаций при использовании тензодатчиков, установленных на прототипе подъемного крана, который был изготовлен согласно предложенной перепроектированной модели.

1. L. Yu, Y. Cao, Q. Chong, and X. Wu, "Reliability-based design for the structure of tower crane under aleatory and epistemic uncertainties," in: Proc. of the Int. Conf. on Quality, Reliability, Risk, Maintenance, and Safety Engineering (June 17-19, 2011), IEEE (2011), pp. 938-943.

2. A. Afeez, Sanjay, and A. Kumar, "Application of CAD and reverse engineering methodology for development of complex assemblies," J. Eng. Des. Technol., 11, No. 3, 375-390 (2013).

3. ISO 8686-1:1989. International Organization for Standardization. International Standard: Cranes - Design Principles for Loads and Load Combinations, Part 1: General, Geneva, Switzerland (1989). 
4. ANSI/SIA A92.2-2009. Standard for Vehicle-Mounted Elevating and Rotaring Aerial Devices, American National Standard Institute (2009).

5. H. Vorhölter, J. Christiansen, and H. Hatecke, "Universal crane model for the ship design system E4," in: Proc. of the 33rd Int. Conf. on Ocean, Offshore, and Arctic Engineering (June 8-13, 2014, San Francisco, CA), ASME (2014), pp. 1-9.

6. A. Sagirli, M. E. Bogoclu, and V. E. Omurlu, "Modeling the dynamics and kinematics of a telescopic rotary crane by the bond graph method: Part I," Nonlinear Dynam., 33, No. 4, 337-352 (2003).

7. A. Sagirli, M. E. Bogoclu, and V. E. Omurlu, "Modeling the dynamics and kinematics of a telescopic rotary crane by the bond graph method: Part II," Nonlinear Dynam., 33, No. 4, 353-367 (2003).

8. M. K. Bak and M. R. Hansen, "Analysis of offshore knuckle boom crane - Part one: Modeling and parameter identification," Model. Ident. Control, 34, No. 4, 157-174 (2013).

9. A. Arena, A. Casalotti, W. Lacarbonara, and M. P. Cartmell, "Three-dimensional modeling of container cranes," in: Proc. of the Int. Design Engineering Technical Conf. and Computers and Information in Engineering Conf. (August 4-7, 2013, Portland, OR), ASME (2013), pp. 1-9.

10. P. F. Liu, L. J. Xing, Y. L. Liu, and Y. Zheng, "Strength analysis and optimal design for main girder of double-trolley overhead traveling crane using finite element method," J. Fail. Anal. Prevention, 14, No. 1, 76-86 (2014).

11. X. Fan and X. Bi, "Reliability-based design optimization for crane metallic structure using ACO and AFOSM based on China standards," Math. Probl. Eng., doi.org/ 10.1155/2015/828930 (2015).

12. V. V. Arun Sankar, P. Deepak Vijayan, and M. Y. Ibrahim Ashraf, "Reducing the structural mass of a real-world double girder overhead crane," Int. J. Adv. Eng. Technol., 8, No. 2, 150-162 (2015).

13. D. Safarzadeh, S. Sulaiman, F. A. Aziz, et al., "The design process of a self-propelled floor crane," J. Terramechanics, 48, No. 2, 157-168 (2011).

14. D. Wu, L. Yuanshan, W. Xin, and W. Xiukun, "Design and realization of crawler crane's lifting simulation system," in: Proc. of the Int. Design Engineering Technical Conf. and Computers and Information in Engineering Conf. (August 3-6, 2008, Brooklyn, NY), ASME (2008), pp. 1523-1531.

15. X. Kong, Z. Qi, and G. Wang, "Elastic instability analysis for slender lattice-boom structures of crawler cranes,” J. Constr. Steel Res., 115, 206-222 (2015).

16. A. Jadhav, M. Kachroo, M. Hegde, et al., "Optimization in design of rotating hydraulic crane," Int. J. Eng. Adv. Technol., 3, No. 2, 76-82 (2013).

17. W. Yang, Y. Li, Z. Fang, and K. He, "Study on dynamic optimum design of tower crane structure," in: Proc. of the Second Int. Conf. on Mechanic Automation and Control Engineering (July 15-17, 2011), IEEE (2011), pp. 1660-1663.

18. A. Karpe, S. Karpe, A. Chawrai, and S. R. Vankar, "Validation of use of FEM (ANSYS) for structural analysis of tower crane jib and static and dynamic analysis of tower crane JIB using ANSYS," Int. J. Innov. Res. Adv. Eng., 1, No. 4, 69-75 (2014).

19. P. R. Patel and V. K. Patel, "A review on structural analysis of overhead crane girder using FEA technique," Int. J. Eng. Sci. Innov. Technol., 2, No. 4, 41-44 (2013).

20. F. Ju, Y. S. Choo, and F. S. Cui, "Dynamic response of tower crane induced by the pendulum motion of the payload," Int. J. Solids Struct., 43, No. 2, 376-389 (2006). 
21. D. S. Han, S. W. Yoo, H. S. Yoon, et al., "Coupling analysis of finite element and finite volume method for the design and construction of FPSO crane," Automat. Constr., 20, No. 4, 368-379 (2011).

22. J. Yao, X. Qiu, Z. Zhou, et al., "Buckling failure analysis of all-terrain crane telescopic boom section," Eng. Fail. Anal., 57, 105-117 (2015).

23. M. Savković, M. Gašić, G. Pavolvić, et al., "Stress analysis in contact zone between the segments of telescopic booms of hydraulic truck cranes," Thin Wall. Struct., 85, 332-340 (2014).

24. J. Wu, "Finite element analysis and vibration testing of a three-dimensional crane structure," Measurement, 39, No. 8, 740-749 (2006).

25. C. B. Pinca, G. O. Tirian, A. V. Socali, and E. D. Ardelean, "Dimensional optimization for the strength structure of a traveling crane," WSEAS Trans. Appl. Theor. Mech., 4, No. 4, 147-156 (2009).

26. A. K. Patel and V. K. Jani, "Design and dynamic analysis of $70 \mathrm{~T}$ double girder electrical overhead crane," J. Inform. Know. Res. Mech. Eng., 2, No. 2, 496-503 (2013).

27. T. Balkan, “A load control system for mobile cranes," Mech. Res. Commun., 23, No. 4, 395-400 (1996).

28. A. Freddi, G. Olmi, and L. Cristofolini, Experimental Stress Analysis for Materials and Structures, Springer International Publishing (2015).

29. E. J. Alzate Rodriguez, J. W. Montes Ocampo, and C. A. Silva Ortega, "Medidores de deformacion por resistencia: galgas extensiométricas," Scientia et Technica, 2, No. 34, 7-12 (2007), doi.org/10.22517/23447214.5519.

30. P. Kulha, A. Boura, and M. Husak, "Design and fabrication of piezoresistive strain-gauges for harsh environment applications," in: Proc. of the Int. Conf. on Renewable Energies and Power Quality (March 23-25, 2010, Granada, Spain), EA4EPQ (2010), pp. 23-25.

31. L. W. Changsheng, "Research on real time monitoring system for the stress in port machinery structure," J. Wuhan Univ. Technol., 2, 1-27 (2007).

32. P. Kulha and M. Husak, "Piezoresistive sensor for strain measurement on turbine blade with wireless telemetry data acquisition," in: Proc. of the Int. Conf. on Renewable Energies and Power Quality, (April 13-15, 2011, Las Palmas de Gran Canaria, Spain), EA4EPQ (2011), p. 2172-038.

33. R. Puers, "Linking sensors with telemetry: impact on the system design," Sensor Actuat. A - Phys., 52, No. 1, 169-174 (1996).

34. A. V. Oppenheim, A. S. Willsky, and S. H. Nawab, Signals and Systems, Pearson (2014).

35. R. Pallas-Areny and J. G. Webster, Sensors and Signal Conditioning, WileyInterscience (2001).

36. Serviacero Comercial. Productos. http://www.serviacero.com/comercial.

37. MatWeb LLC. Material Property Data. http://www.matweb.com/index.aspx. 